Since these observations were first made numerous investigators have studied the problem and have in the main confirmed the results, but recently Lorenz described an outbreak of $Y$ dysentery in a Hamburg orphan asylum, which he believes, as the result of clinical and experimental evidence, to have originated from boiled milk infected with Bacillus dysenterice $I^{r}$ in the orphanage kitchen. It is true that pasteurisation will afford some sort of protection against such diseases as diphtheria, scarlet fever, and enteric, but taking into consideration the fact that young infants are more or less immune against such diseases in virtue of their harbouring a considerable number of immune bodies transferred to them by the mother during their intra. life, the danger of communicating such diseases during non-epidemic periods, at any rate to very young infants, is almost insignificant. Whilst therefore the risk of conveying infectious diseases by means of raw milk is very slight, the danger of setting up intestinal putrefaction in infants on administering heated milk is very considerable.

I am, Sir, yours faithfully,

London, W., March 7th, 1921. W. M. FELDMAN, M.D.

\section{DANGEROUS DRUGS ACT, 1920.}

$$
\text { To the Editor of THE LANCET. }
$$

SIR,-A perusal of the Draft Regulations, made under the Dangerous Drugs Act, 1920, indicated they were rather unsuitable for hospital practice for reasons which need not now be stated. Representations were therefore made on behalf of hospitals, and a series of interviews took place at the Home Office at which the question was fully discussed, with the result that special regulations are being evolved which should prove quite acceptable to these institutions.

Although it is at the moment not permissible to give details, yet it may be stated that these new regulations will not add to the duties of the members of the medical and surgical staffs, and that for the hospital pharmacist they will involve very little more than the adaptation of the existing organisation of the hospital dispensary to meet a special set of circumstances.

I am, Sir, yours faithfully,

$$
\text { F. A. HOCKING, }
$$

March 3rd, 1921

$$
\text { Pharmaceutist to the London Hospital. }
$$

To the Editor of THE LANCET.

SIR,-The Council of the London and Counties Medical Protection Society, Ltd., which represents over 6000 members of the medical and dental professions, at its last meeting decided to offer strenuous opposition to the proposed Regulations under the Dangerous Drugs Act, 1920.-I am, Sir, yours faithfully,

\section{HUGH WOODS,}

General Secretary, London and Counties Medical Protection Society, Ltd.

Craven-street, Strand, W.C., March 4th, 1921.

\section{PSEUDO-COXALGIA.}

To the Editor of THE LANCET.

SIR,-I should like to associate myself with some of the remarks of my friend, Mr. A. S. Blundell Bankart, on the nature of the "recovery" in pseudo-coxalgia. It is true that in this disease during childhood, with a radiographic picture showing an extreme deformation of the head of the femur, there may be a complete absence of limp and shortening, and the limitation of abduction may at the moment in no way cause any true disability. Out of 17 cases I have under observation at the present time this grade of "recovery" is present in eight. But it is essential to remember that such an alteration in the mechanics of the hip-joint is likely to produce trouble in adult life. The radiographic endresult in these cases is an enlarged flattened head which is far too big for the acetabulum. This is shown quite conclusively in a number of my radiograms of hip-joints in adults who give a clear history of pseudocoxalgia in childhood. In later life such hip-joints stand wear and tear badly, and may progress towards an osteo-arthritic stage. The limitation of abduction is now a serious defect.
For this reason I hold with Mr. Bankart that it is advisable to treat all cases of pseudo-coxalgia in the early stage by complete relief from weight-bearing, and further, to maintain for a considerable time the position of abduction. This was originally recommended by Mr. Muirhead Little in 1915. I must confess that in my earlier cases I adopted a laissez-faire attitude, but in my more recent cases I have felt constrained to treat them as one does the initial stages of true tuberculous arthritis. I am, Sir, yours faithfully

Manchester, March 5th, 1921. Harry Platt.

\section{To the Editor of THE LANCET.}

SIR,-Mr. A. S. Blundell Bankart has done service to many patients by pointing out that in the above con dition the advice, "No treatment is necessary," is wrong. Because the disease is not the ordinary hip disease, and may not be tuberculous, surgeons have hastened to excuse their patients from prolonged and perhaps irksome immobilisation, with regrettable results in shortening, limitation of movement, and consequent limp. Mr. Bankart, I think, is not alone in the method of treatment he adopts. Dr. Rollier, in his heliotherapy clinic at Leysin, has for years given up making any distinction as regards treatment between these cases and the ordinary cases of hip disease. All alike are treated by recumbency and extension until a radiogram shows regeneration of the head of the bone. I am, Sir, yours faithfully,

Harley-street, W., March 5th, 1921. PAUL BERnARD RoTH.

\section{TREATMENT OF DIPHTHERIA CARRIERS}

\section{To the Editor of THE LANCET.}

SIR,-In bringing my correspondence on the above subject to an end, I thank Dr. A. G. B. Duncan for recapitulating his "views and intentions" (1'HE LANCET, Feb. 26th, p. 459). Let me say that I still find myself unable to appreciate the necessity for his differentiation between "carrier" and "positive throat," and my hope is that with the more universal application of vaccine therapy (which Dr. Duncan agreed was effective in the "positive throat") the necessity will no longer arise for the term "carrier," as it does not appear wise to allow any "positive throat" to persist for such a length of time as would warrant the former "distinction." It would be matter for real regret if inaction in the first instance provided material for future experiment.-I am, Sir, yours faithfully,

JAMES LAW BROWNLIE.

Glasgow Corporation Laboratory, March 5th, 1921

\section{THE INTERNATIONAL UNION AGAINST TUBERCULOSIS : \\ A CONFERENCE IN LONDON. \\ To the Editor of THE LANCET.}

SIR, - The next International Conference will be held in London from Tuesday, July 26th, to Thursday, July 28th, inclusive. The Conference will be open to members of the International Union against Tuberculosis and to delegates from countries within the League of Nations, and from the United States of America. The president of the International Union for the current year is Mons. Léon Bourgeois, President of the French Senate, who will be succeeded on the occasion of the Conference in London by Professor Sir Robert Philip of the University of Edinburgh. It is hoped that the opening address of the Conference will be given by Mons. Léon Bourgeois. The arrangements for the Conference are under the charge of the executive committee of the International Union in correspondence with the Council of the National Association for the Prevention of Tuberculosis.

The subjects proposed for discussion include the following: (1) The Modes of Diffusion of Tuberculosis throughout the Races of the World, to be opened by Professor Calmette; (2) the Rôle of the Medical Profession in the Prevention of Tuberculosis.

In the name of the International Union,

I am, Sir, yours faithfully,

\section{LEON BERNARD,}

